\title{
Analisis finansial peremajaan perkebunan sawit rakyat di Kabupaten Muaro Jambi
}

\author{
Saad Murdy*; Saidin Nainggolan*; Dompak Napitupulu \\ Jurusan Agribisnis Fakultas Pertanian Universitas Jambi \\ *E-mail korespodensi: saadmurdy@unja.ac.id
}

\begin{abstract}
This study aims to (1) determine the feasibility of smallholder oil palm plantations assessed from a financial perspective using investment criteria, (2) determine the sensitivity of smallholder oil palm plantations to changes in input and output prices. This research was conducted in Muaro Jambi Regency. The method of analysis used an analysis of investment criteria consisting of $N P V, I R R, B C R, P B P$, and BEP. The data used were primary data obtained through interviews using questionnaires. Samples were taken by snowball sampling of 40 small independent smallholders of Muaro Jambi Regency. The results showed that smallholder oil palm plantations, conventional rejuvenation, and underplanting rejuvenation were feasible to be cultivated. The results of the sensitivity analysis on the increase in the price of production factors by $15 \%$ and the selling price of FFB is considered constant, and the selling price of FFB has decreased by $15 \%$ and the price of production factors is fixed, both types of oil palm plantation rejuvenation are still feasible to carry out. Changes in FFB prices are more sensitive to changes in the value of investment criteria than changes in the price of production factors.
\end{abstract}

Keywords: Rejuvenation, Feasibility, Conventional, Underplanting.

\begin{abstract}
Abstrak
Penelitian ini bertujuan untuk (1) mengetahui kelayakan perkebunan sawit rakyat dinilai dari sisi finansial dengan menggunakan kriteria investasi, (2) mengetahui sensitivitas perkebunan sawit rakyat terhadap perubahan harga input dan output. Penelitian ini dilaksanakan di Kabupaten Muaro Jambi .Metode analisis menggunakan analisis kriteria investasi yang terdiri dari NPV, IRR, BCR, PBP dan BEP.Data yang digunakan adalah data primer yang diperoleh melalui wawancara dengan menggunakan quisioner. Sampel diambil secara snowball Sampling sebanyak 40 petani sawit rakyat swadaya murni Kabupaten Muaro Jambi. Hasil penelitian menunjukkan bahwa perkebunan sawit rakyat, peremajaan konvensional dan peremajaan underplanting layak untuk diusahakan. Hasil analisis sensitivitas terhadap kenaikan harga faktor produksi sebesar $15 \%$ dan harga jual TBS dianggap tetap, serta harga jual TBS turun sebesar $15 \%$ dan harga faktor produksi tetap, kedua jenis peremajaa kebun sawit masih layak untuk dilaksanakan. Perubahan harga TBS lebih sensitif terhadap perubahan nilai kriteria investasi dibandingkan perubahan harga faktor produksi.
\end{abstract}

Kata kunci: Peremajaan, Kelayakan, Konvensional, Underplanting. 


\section{PENDAHULUAN}

Perkebunan sawit mempunyai peran sangat penting dalam perekonomian di Indonesia. Komoditas sawit merupakan salah satu komoditi ekspor Indonesia penghasil devisa yang besar untuk negara sesudah minyak dan gas. Perkebunan sawit adalah salah satu tanaman perkebunan sebagai penyedia lapangan kerja, sumber pendapatan dan devisa Negara. Perkebunan sawit mampu menyediakan lapangan kerja dan sumber pendapatan bagi 4,42 juta kepala keluarga pada tahun 2018 menyumbang devisa sebesar US\$120,654 miliar (Juliansyahet al, 2020). Indonesia memiliki posisi strategis untuk mengembangkan subsektor perkebunan dan sebagai Negara produsen dan eksportir kelapa sawit terbesar di dunia (Badan Pusat Statistik, 2018).

Indonesia adalah negara dengan luas areal kelapa sawit terbesar di dunia, yaitu sebesar 34,18 persen dari luas areal kelapa sawit dunia namun menempati posisi kedua dalam hal produksi dengan jumlah mencapai 18 juta ton pertahun (Arianto, 2008). Produksi dan luas areal di Indonesia cenderung meningkat setiap tahunnya. Tahun 2018, luas areal 14,33 juta ha dan produksi 42,9 juta ton, Tahun 2019 luas areal menjadi 16,38 juta ha dengan produksi 48,42 juta ton, target produksi CPO sebanyak 40 juta ton tahun 2020 (Badan Pusat Statistik, 2018).

Perkembangan luas areal perkebunan sawit Indonesia selama lima tahun terakhir cenderung mengalami peningkatan, kecuali pada tahun 2016 yang mengalami penurunan. Kenaikan tersebut berkisar antara 2,77 sampai dengan 10,55 persen per tahun dan mengalami penurunan pada tahun 2016 sebesar 0,52 persen. Pada tahun 2014 lahan perkebunan kelapa sawit Indonesia tercatat seluas 10,75 juta hektar, meningkat menjadi 11,26 juta hektar pada tahun 2015 atau terjadi peningkatan 4,70 persen. Pada tahun 2016 luas areal perkebunan kelapa sawit menurun sebesar 0,52 persen dari tahun 2015 menjadi 11,20 juta ha. Tahun 2017 luas areal perkebunan kelapa sawit kembali mengalami peningkatan sebesar 10,55 persen dan diperkirakan meningkat tahun 2018 menjadi 14,33 juta ha. Menurut status pengusahaannya, sebagian besar perkebunan kelapa sawit pada tahun 2018 yaitu Perkebunan Rakyat sebesar 5,81 juta ha (45,54\%), Perkebunan Besar Negara sebesar 0,59 juta ha (4,65\%), dan Perkebunan Besar Swasta sebesar 6,36 juta ha $(49,81 \%)$ (Badan Pusat Statistik, 2018).

Perkembangan sektor perkebunan sawit telah memberikan sumbangan nyata terhadap peningkatan kondisi ekonomi masyarakat pada tingkat nasional serta daerah.Perkebunan sawit merupakan salah satu komoditas yang memiliki prospek pengembangan yang cukup cerah (Tarigan et al, 2014). Provinsi Jambi merupakan salah satu daerah penghasil utama sawit dan menjadikannya sebagai komoditas unggulan. Perkebunan rakyat mencapai 53 persen, menyusul perkebunan perusahaan besar swasta 40,9 persen dan sisanya 6,1 persen merupakan perkebunan perusahaan Negara. Meskipun luasan perkebunan rakyat yang terluas, tetapi produksi, baik dari segi kuantitas dan kualitas, perkebunan sawit rakyat tetap saja kalah jika dibanding produksi perusahaan besar Negara dan perusahaan swasta. Produksi perkebunan sawit rakyat hanya 11,4 ton per hektar per tahun.

Kabupaten Muaro Jambi merupakan salah satu daerah di Provinsi Jambi sebagai sentra perkebunan sawit rakyat terluas yaitu 97,630 ha atau sebesar $21,23 \%$ dari total luas lahan perkebunan sawit di Provinsi Jambi dan Kecamatan Sungai Bahar merupakan daerah dengan luas perkebunan sawit rakyat terluas di Kabupaten Muaro 
Jambi yaitu 32,312 ha atau 33,10\% dengan total produktivitas kelapa sawit yang masih rendah dibandingkan dengan kecamatan yang lainnya. Hal ini disebabkan oleh areal tanaman tidak menghasilkan (TTM) yang sangat luas yaitu 11,930 ha. Kondisi ini berdampak pada rendahnya produksi dan pendapatan petani per hektarnya. Menurut Ginting et al , 2008 peremajaan kelapa sawit dapat dilakkukan ketika umur tanaman telah melampaui umur ekonomis yaitu sekitar 25 tahun dengan produktivitas dibawah 12 ton TBS/ha/tahun yang mengakibatkan pendapatan yang diperoleh oleh petani menurun, kesulitan panen dikarenakan tanaman tinggi dan menyulitkan pemanenan sehingga efektivitas panen rendah,kerapatan tanaman, dimana areal dengan kerapatan rendah tidak ekonomis untuk dikelola sehingga perlu diremajakan. Persoalan produksi yang sedikit dan kualitas yang rendah ini ditambah pula dengan persoalan lainnya yakni harga yang diterima petani tidak memiliki posisi tawar (bargaining position) yang tinggi di pabrik-pabrik kelapa sawit untuk itu perlu dilakukan penilaian investasi untuk memberikan verifikasi terkait dengan kelayakan finansial peremajaan kebun sawit teknik konvensional dan underplanting

\section{METODE}

Lokasi penelitian adalah Kabupaten Muaro Jambi. Sumber data primer diperoleh langsung dari petani sawit yang melakukan peremajaan. Sumber data sekunder sebagai data pendukung diperoleh dari Dinas Perkebunan Provinsi Jambi.Penelitian dilaksanakan pada bulan Juli hingga Agustus 2020. Data primer diperolehmelalui wawancara dengan kuisioner pada petani. Penarikan sampel dengan metode snowball sampling sebanyak 40 petani yakni 20 petani melakukan peremajaan kebun sawit dengan pola konvensional dan 20 petani dengan pola underplanting.

Metode analisis data menggunakan metode deskriptif dan alat analisis yang digunakan adalah analisis kelayakan investasi dari aspek finansial Ibrahim (2009) dengan menggunakan kriteria : analisis arus kas, Net Benefit Costs Ratio (Net B/C Ratio), Net Prevent Value (NPV), Internal Rate of Return (IRR), Payback Period dan analisis sensitivitas.

\section{Analisis arus kas (Cash flow)}

Analisis arus kas (Cash flow) adalah perbandingan antara hasil penjualan dengan jumlah biaya-biaya, analisis ini terdiri dari beberapa segi yaitu: 1). Cash in flow: Mencatat semua bentuk pemasukan baik pemasukan yang berasal dari penjualan hasil maupun berasal dari peminjaman kredit atau penyertaan nasabah. 2).Cash out flow: Mencatat semua pengeluaran khususnya pengeluaran untuk investasi, operasi, dan pengembalian kredit.

\section{Net benefit cost ratio (Net B/C Ratio)}

Net benefit cost ratio (Net B/C Ratio) Ibrahim (2009) adalah sebagai berikut :

Net $\mathrm{B} / \mathrm{C}=\frac{\sum_{i=1}^{n} \frac{B i}{(1+r)^{n}}}{\sum_{i=1}^{n} \frac{C i}{(1+r)^{n}}}$ 
Dimana:

Net $\mathrm{B} / \mathrm{C}=$ Net $\mathrm{B} / \mathrm{C}$ ratio

$\mathrm{B}_{\mathrm{i}} \quad=$ Penerimaan (benefit)

$\mathrm{C}_{\mathrm{i}} \quad=$ Pengeluaran (cost)

$\mathrm{N} \quad=$ Waktu

$(1+\mathrm{r})^{\mathrm{n}}=$ Discounting factor $(\mathrm{Df})$

$\mathrm{R} \quad=$ Tingkat bunga/ social discount rate (\%), tingkat bunga yang dipakai merupakan tingkat bunga investasi rata-rata selama periode penelitian.

Net Present Value (NPV) Ibrahim (2009), adalah sebagai berikut :

$\mathrm{NPV}=\left[\sum_{1=1}^{n} \frac{N B i}{(1+i)^{n}}\right]$

Dimana:

NPV = Net present value (nilai netto sekarang)

$\mathrm{NB}_{\mathrm{i}} \quad=$ Net benefit $=$ benefit - cost

$\mathrm{n} \quad=$ Tahun (waktu)

$\mathrm{i} \quad=$ Tingkat bunga/social discount rat $(\%)$, yaitu tingkat bunga yang dipakai merupakan tingkat bunga investasi rata-rata selama periode peneliti

$\frac{1}{(1+i)^{n}}=$ Discounting factor

Internal Rate of Return (IRR) Ibrahim (2009) sebagai berikut,

$\mathrm{IRR}=\left[\frac{N P V_{1}}{N P V_{1}-N P V_{2}}\right] x\left(i_{2}-i_{1}\right)$

Dimana:

IRR = Internal Rate of Return

$\mathrm{NPV}_{1}=\mathrm{NPV}$ dari discount rate yang rendah

$\mathrm{NPV}_{2}=\mathrm{NPV}$ dari discount rate yang tinggi

$\mathrm{i}_{1} \quad=$ Tingkat discount rate menghasilkan $\mathrm{NPV}_{1}$

$\mathrm{i}_{2} \quad=$ Tingkat discount rate menghasiilkan $\mathrm{NPV}_{2}$

Payback period (masa pelunasan kembali) Ibrahim (2009) adalah :

$\mathrm{PBP}=\mathrm{T}_{\mathrm{p}-1} \frac{\sum_{i=1}^{n} \overline{\mathrm{I}} i-\sum_{i=1}^{n} B_{i c p-1}}{B_{p}}$

Dimana:

$\mathrm{PBP}=$ Payback period

$\mathrm{T}_{\mathrm{p}-1} \quad=$ Tahun sebelum terdapat PBP

$\mathrm{I}_{\mathrm{i}} \quad$ = Jumlah investasi yang telah di-discount

$\mathrm{B}_{\text {icp-1 }}=$ Jumlah benefit yang telah di-discount sebelum payback period

$\mathrm{B}_{\mathrm{p}} \quad=$ Jumlah benefit pada payback period 
Analisis sensitivitas merupakan alat analisis untuk melihat apa yang terjadi dengan hasil analisis proyek jika ada suatu mengalami kesalahan dapat dituliskan sebagai berikut :

$(\mathrm{NPV}=0 \%)=\frac{\text { Tingkat inflasi }}{\text { Perubahan } N P V} \times 100 \%$

\section{HASIL DAN PEMBAHASAN}

\section{Biaya membangun kebun sawit teknik kovensional}

Membangun kebun peremajaan teknik kovensional dengan menggunakan dana APBN dan BPDPKS terdiri dari tahapan dan alokasi biaya. seperti Tabel 1.

Tabel 1.Rincian biaya pada kegiatan membangun kebun peremajaan dana APBN dan BPDPKS di daerah penelitian Tahun 2019

\begin{tabular}{lrr}
\hline \multirow{2}{*}{ Uraian kegiatan } & \multicolumn{2}{c}{ Jumlah Biaya (Rp/Ha) } \\
\cline { 2 - 3 } & APBN 2012 & BPDPKS 2018 \\
\hline Tambang chipping+lobang bonggol & & 10.000 .000 \\
Pokok tua+bahan tricoderma & & \\
Tumbang + rempuk & 5.000 .000 & 1.900 .000 \\
Membajak tanah & & 150.000 \\
Membersihkan jalur tanam & 150.000 & 150.000 \\
Pemancangan & 150.000 & 105.000 \\
Kayu pancang & 105.000 & 1.500 .000 \\
Lubang dan tanam & 1.250 .000 & 600.000 \\
Distribusi bibit ke lubang tanam & 600.000 & 69.500 \\
Pupuk dasar & 69.750 & 1.500 .000 \\
Turunkan bibit dari mobil & 1.500 .000 & 6.000 .000 \\
Pembelian bibit & 3.750 .000 & 395.000 \\
Pembelian alat-alat & 1.076 .033 & $\mathbf{2 2 . 3 6 9 . 5 0 0}$ \\
\hline \multicolumn{1}{c}{ Jumlah } & $\mathbf{1 3 . 6 5 0 . 7 8 3}$ & \\
\hline
\end{tabular}

Sumber: Data diolah, 2020

Tabel 1 menunjukkan bahwa biaya membangun kebun peremajaan teknik konvensional dengan dana APBN sebesar Rp. 13.65 juta per ha dan biaya dengan dana BPDPKS sebesar Rp. 22.37 juta per ha. Perbedaan antara kedua pendanaan tersebut karena pada dana APBN tidak terdapat biaya kegiatan membajak tanah dan kegiatan penumbangan. Biaya terbesar pada pendanaan peremajaan BPDPKS yaitu kegiatan tumbang chipping dan lobang bonggol pokok tua dan bahan tricoderma sebesar Rp. 10.juta sedangkan dana APBN biaya terbesar pada kegiatan tumbang dan rumpuk sebesar Rp. 5.juta dan untuk biaya terendah pada peremajaan dana BPDPKS pupuk dasar sebesar Rp. 69.500 dan peremajaan dana APBN yaitu pupuk dasar sebesar Rp. 69.750.

\section{Membangun kebun sawit teknik underplanting}

Teknik underplanting pembukaan lahan dilakukan secara bertahap dan menggunakan bahan kimia untuk membunuh batang kelapa sawit tua serta tidak 
memerlukan pengolahan tanah.Adapun biaya membangun kebun peremajaan teknik underplanting dapat dilihatTabel 2.

Tabel 2. Rincian biaya pada kegiatan membangun kebun peremajaan teknik underplanting di daerah penelitian Tahun 2019

\begin{tabular}{lc}
\hline \multicolumn{1}{c}{ Uraian kegiatan } & Jumlah biaya (Rp) \\
\hline Pemancangan & 50.500 \\
Kayu pancang & 57.083 \\
Lubang dan tanam & 503.167 \\
Peracunan & 733.333 \\
Pembelian bibit & 1.815 .850 \\
Pembelian alat-alat & 1.002 .400 \\
\hline \multicolumn{1}{c}{ Jumlah } & $\mathbf{4 . 1 6 2 . 3 3 3}$ \\
\hline
\end{tabular}

Sumber: Data diolah, 2020

Tabel 2 menunjukkan bahwa membangun kebun peremajaan teknik underplanting adalah sebesar Rp. 4.16 juta per ha. Perbedaan biaya membangun kebun peremajaan teknik konvensional dan teknik underplanting karena kegiatan yang dilakukan lebih intensif dibandingkan teknik underplanting.

\section{Pemeliharaan teknik konvensional}

Biaya rata-rata pemeliharaan kebun teknik konvensional dengan dana APBN sebesar Rp. 1.78 juta sedangkan dengan dana BPDPKS sebesar Rp. 3.74 juta Biaya terbesar terdapat pada tahun ketiga karena tahun ketiga tanaman mulai berproduksi sehingga memerlukan dosis pupuk yang lebih banyak. Biaya pemeliharaankebun peremajaan teknik konvensional dapat dilihat Tabel 3.

Tabel 3. Rincian biaya pada tahapan perawatan peramajaan teknik konvensional s/d usia menghasilkan

\begin{tabular}{|c|c|c|c|c|c|c|}
\hline \multirow{3}{*}{$\begin{array}{c}\text { Uraian } \\
\text { Perawatan } \\
\text { Tahun }\end{array}$} & \multicolumn{6}{|c|}{ Jumlah Biaya (Rp) } \\
\hline & \multicolumn{2}{|c|}{1} & \multicolumn{2}{|c|}{2} & \multicolumn{2}{|c|}{3} \\
\hline & APBN & BPDPKS & APBN & BPDPKS & APBN & BPDPKS \\
\hline \multicolumn{7}{|l|}{ Obat-obatan } \\
\hline Round UP & 87.733 & 476.000 & 94.500 & 340.000 & 165.667 & 272.000 \\
\hline Gramaxon & 63.600 & 231.000 & 147.500 & 165.000 & 149.633 & 132.000 \\
\hline $\begin{array}{l}\text { Upah } \\
\text { Pekerja }\end{array}$ & 205.214 & 187.000 & 146.929 & 187.000 & 197.119 & 150.000 \\
\hline \multicolumn{7}{|l|}{ Pemupukan } \\
\hline Urea & 128.469 & 351.000 & 288.600 & 702.000 & 545.020 & 1.170 .000 \\
\hline SP-36 & 151.827 & 337.500 & 399.681 & 878.500 & 648.833 & 1.125 .000 \\
\hline KCL & 207.627 & 585.000 & 583.950 & 1.462 .500 & 661.810 & 1.462 .000 \\
\hline $\begin{array}{l}\text { Upah } \\
\text { Pekerja }\end{array}$ & 177.500 & 337.500 & 145.000 & 337.500 & 143.571 & 337.500 \\
\hline Jumlah & 1.021 .970 & 2.505.500 & 1.805 .642 & 4.073.000 & 2.511.654 & 4.649 .000 \\
\hline
\end{tabular}

Sumber: Data diolah, 2020

Berdasarkan Tabel 3 menunjukkan bahwa rata-rata biaya obat-obatan yang dikeluarkan petani dalam kegiatan perawatan peremajaan teknik konvensional dengan dana APBN adalah sebesar Rp. 0,41 juta pertahun/Ha sedangkan untuk biaya obatobatan pada dana BPDPKS sebesar Rp. 0,71 juta . Biaya rata-rata pemupukan yang 
dikeluarkan petani responden dalam kegiatan perawatan dengan dana demplot sebesar Rp. 1,36 juta sedangkan biaya pemupukan pada dana BPDPKS sebesar Rp. 3,02 juta.

\section{Pemeliharaan kebun teknik underplanting}

Biaya rata-rata pemeliharaan pada teknik underplanting sebesar Rp.1,80 juta. Biaya terbesar yang dikeluarkan petani terdapat pada tahun kelima dikarenakan pada tahun kelima tanaman mulai berproduksi maka memerlukan dosis yang lebih banyakdapat dilihat Tabel 4.

Tabel 4. Rincian biaya pada tahapan perawatan peremajaan teknik underplanting s/d usia menghasilkan

\begin{tabular}{lrrrrr}
\hline \multirow{2}{*}{$\begin{array}{l}\text { Uraian kegiatan } \\
\text { perawatan tahun }\end{array}$} & \multicolumn{5}{c}{ Jumlah biaya (Rp) } \\
\cline { 2 - 6 } & \multicolumn{1}{c}{$\mathbf{1}$} & $\mathbf{2}$ & $\mathbf{3}$ & $\mathbf{4}$ & \multicolumn{1}{c}{$\mathbf{5}$} \\
\cline { 2 - 6 } Obat-obatan & 73.405 & 67.234 & 95.401 & 108.994 & 153.738 \\
Round UP & 55.332 & 61.140 & 86.788 & 125.187 & 158.340 \\
Gramaxon & 226.920 & 107.990 & 143.440 & 180.578 & 244.760 \\
Upah Pekerja & & & & & \\
Semprot & 166.518 & 208.878 & 267.960 & 295.408 & 248.066 \\
Pemupukan & 108.576 & 102.080 & 189.466 & 285.824 & 401.940 \\
Urea & 255.200 & 271.440 & 325.380 & 482.676 & 578.550 \\
SP-36 & 214.020 & 418.528 & 615.186 & 788.104 & 1.057 .224 \\
KCL & 36.888 & 29.615 & 53.650 & 90.809 & 73.513 \\
NPK & 143.178 & 143.178 & 186.428 & 229.928 & 297.270 \\
Dolomit & & & & \\
Upah Pekerja & $\mathbf{1 . 2 8 0 . 0 3 7}$ & $\mathbf{1 . 4 1 0 . 0 8 3}$ & $\mathbf{1 . 9 6 3 . 6 9 9}$ & $\mathbf{2 . 5 8 7 . 5 0 8}$ & $\mathbf{3 . 2 1 3 . 4 0 1}$ \\
Pemupukan & \multicolumn{1}{c}{ Jumlah } & & & & \\
\hline
\end{tabular}

Sumber: Data diolah, 2020

Tabel 4 menunjukkan bahwa biaya obat-obatan kegiatan pemeliharaan peremajaan teknik underplanting adalah sebesar Rp. 0,37 juta pertahun/Ha.Biaya terbesar terdapat pada tahun kelima karena pada tahun kelima pokok tanaman semakin tinggi dan gulma berada dibawah pokok sawit ternaungi serta tanah menjadi lembab.Tanah yang lembab mengakibatkan pertumbuhan gulma semakin meningkat dan diperlukan pemeliharaan yang intensip. Rata-rata biaya pemupukan kebun peremajaan teknik underplanting sebesar Rp. 1,50 juta pertahun/Ha. Biaya terbesar terdapat pada tahun lima karena pada tahun lima kebun mulai berproduksi maka memerlukan dosis yang lebih banyak.

\section{Biaya investasi}

Biaya investasi adalah biaya yang hanya dikeluarkan sekali selama umur ekonomis tanaman kelapa sawit (Utomo et al, 2016). Adapun penggunaan biaya investasi yang dikeluarkan petani peremajaan teknik konvensional dan teknik underplanting yaitu biaya membangun kebun, biaya variabel dan biaya tetap. Biaya investasi dapat dilihat Tabel 5. 
Tabel 5. Biaya investasi peremajaan teknik konvensional di daerah penelitian

\begin{tabular}{lccc}
\hline \multicolumn{1}{c}{ Tahapan } & Tahun $\mathbf{1}$ & Tahun $\mathbf{2}$ & Tahun 3 \\
\hline Membangun & 14.586 .710 & 0 & 0 \\
Kebun & $\mathbf{1 4 . 5 8 6 . 7 1 0}$ & $\mathbf{0}$ & $\mathbf{0}$ \\
Total & & & \\
Biaya Variabel & 565.991 & 1.412 .547 & 2.152 .569 \\
Pemupukan & 175.546 & 280.720 & 365.748 \\
Obat & 285.416 & 224.516 & 271.716 \\
TKDK & 158.534 & 114.122 & 123.484 \\
TKLK & $\mathbf{1 . 1 8 5 . 4 8 5}$ & $\mathbf{2 . 0 9 4 . 5 4 5}$ & $\mathbf{2 . 9 1 3 . 5 1 9}$ \\
Total Biaya & & & \\
Variabel & 0 & 0 & 0 \\
Biaya Tetap & 0 & 107.165 & 180.332 \\
Pembelian Alat & 1.248 .198 & 58.000 & 58.000 \\
Penyusutan Alat & 0 & $\mathbf{1 6 5 . 1 6 5}$ & $\mathbf{2 3 8 . 3 3 2}$ \\
Pajak & $\mathbf{1 . 2 4 8 . 1 9 8}$ & $\mathbf{2 . 2 5 9 . 7 1 0}$ & $\mathbf{3 . 1 5 1 . 8 5 1}$ \\
Total Biaya Tetap & $\mathbf{1 7 . 0 2 0 . 3 9 3}$ & & \\
\hline \multicolumn{1}{c}{ Total ourflow } & &
\end{tabular}

Sumber: Data diolah, 2020

Tabel 5 menunjukkan bahwa biaya investasi pada peremajaan teknik konvensional tahun pertama sebesar Rp. 17,02 juta, biaya pada tahun kedua adalah sebesar Rp. 2.26 juta, dan biaya pada tahun ketiga adalah sebesar Rp. 3,15 juta.Biaya investasi terbesar adalah untuk melakukan pembukaan lahan. Pembukaan lahan pada peremajaan teknik konvensional dilakukan dengan kerja sama pada pihak ketiga yaitu kontraktor untuk melakukan kegiatan tumbang dan rumpuk. Total biaya investasi pada peremajaan teknik konvensional sebesar Rp. 22,43 juta/ ha. Terdapat perbedaan biaya investasi pada peremajaan teknik konvensional dan teknik underplanting.Rincian Biaya investasi peremajaan teknik underplanting dapat dilihat Tabel 6.

Tabel 6. Biaya investasi pada peremajaan teknik underplanting di daerah penelitian

\begin{tabular}{lccccc}
\hline \multicolumn{1}{c}{ Uraian } & Tahun 1 & Tahun 2 & Tahun 3 & Tahun 4 & Tahun 5 \\
\hline Membangun & 3.664 .942 & 0 & 0 & 0 & 0 \\
$\begin{array}{l}\text { Kebun } \\
\text { Total biaya } \\
\text { biaya variabel }\end{array}$ & $\mathbf{3 . 6 6 4 . 9 4 2}$ & $\mathbf{0}$ & $\mathbf{0}$ & $\mathbf{0}$ & $\mathbf{0}$ \\
Pemupukan & & & & & \\
Obat & 772.154 & 1.030 .541 & 1.451 .644 & 1.941 .821 & 2.359 .293 \\
TKDK & 128.737 & 128.374 & 182.187 & 234.181 & 312.078 \\
TKLK & 127.577 & 124.154 & 158.658 & 183.778 & 260.150 \\
Total biaya & 126.846 & 127.014 & 171.210 & 226.730 & 281.880 \\
variabel & $\mathbf{1 . 2 8 0 . 0 3 7}$ & $\mathbf{1 . 4 1 0 . 0 8 1}$ & $\mathbf{1 . 9 6 3 . 6 9}$ & $\mathbf{2 . 5 8 6 . 5 1 0}$ & $\mathbf{3 . 2 1 3 . 4 0 1}$ \\
biaya tetap & & & & & \\
Pembelian Alat & 1.162 .784 & 0 & 0 & 0 & 0 \\
Penyusutan Alat & 0 & 110.545 & 148.204 & 142.165 & 144.081 \\
Pajak & 0 & 58.000 & 58.000 & 58.000 & 58.000 \\
Total biaya tetap & $\mathbf{1 . 1 6 2 . 7 8 4}$ & $\mathbf{1 6 8 . 5 4 5}$ & $\mathbf{2 0 6 . 2 0 4}$ & $\mathbf{2 0 0 . 1 6 5}$ & $\mathbf{2 0 2 . 0 8 1}$ \\
\hline \multicolumn{1}{c}{ Total outflow } & $\mathbf{6 . 1 0 7 . 7 6 3}$ & $\mathbf{1 . 5 7 8 . 6 2 6}$ & $\mathbf{2 . 1 6 9 . 9 0 3}$ & $\mathbf{2 . 7 8 6 . 6 7 5}$ & $\mathbf{3 . 4 1 5 . 4 8 2}$ \\
\hline
\end{tabular}

Sumber: Data diolah, 2020 
Tabel 6 menunjukkan bahwa biaya investasi peremajaan teknik underplanting tahun pertama adalah sebesar Rp. 6.11 juta, biaya pada tahun kedua adalah sebesar Rp. 1.58 juta, biaya pada tahun ketiga adalah sebesar Rp. 2.17 juta, biaya pada tahun keempat adalah sebesar Rp. 2.79 juta dan biaya pada tahun kelima adalah sebesar Rp. 3.42 juta. Jadi total biaya investasi pada peremajaan teknik underplanting sebesar Rp. 16.06 juta. Biaya terbesar yang dikeluarkan petani pada kegiatan investasi terdapat pada tahun pertama karena petani melakukan pembukaan lahan.untuk underplanting

pendapatan kebun sawit peremajaan teknik konvensional dan underplanting. Besarnya pendapatan perkebunan sawit pada teknik peremajaan konvensional dan teknik underplanting dapat dilihat Tabel 7.

Tabel 7.Rata-rata pendapatan perkebunan sawit peremajaan teknik konvensional dan teknik peremajaan undeplanting di daerah penelitian tahun 1 sampai 25.

\begin{tabular}{|c|c|c|c|}
\hline \multirow{2}{*}{ No } & \multirow{2}{*}{ Uraian } & \multicolumn{2}{|c|}{ Teknik Peremajaan } \\
\hline & & Konvensional & Underplanting \\
\hline \multicolumn{4}{|c|}{ A. Penerimaan } \\
\hline 1. & Produksi (Kg) & 24.326 & 11.209 \\
\hline \multirow[t]{2}{*}{2.} & $\operatorname{Harga}(\mathrm{Rp})$ & 1.515 & 1.515 \\
\hline & & 31.770 .285 & 14.625.031 \\
\hline \multicolumn{4}{|c|}{ B. Biaya Yang Tidak Dibayarkan } \\
\hline 1. & Biaya Penyusutan Alat & 145.978 & 134.345 \\
\hline \multirow[t]{2}{*}{2.} & Biaya TKDK & 1.529 .954 & 1.474 .091 \\
\hline & & 1.676 .002 & 1.608 .436 \\
\hline \multicolumn{4}{|c|}{ C. Biaya Yang Dibayarkan } \\
\hline 1. & Pembelian Alat & 49.928 & 46.511 \\
\hline 2. & Pembukaan Lahan & 583.468 & 146.597 \\
\hline 3. & Biaya Pupuk & 4.632 .455 & 4.775 .275 \\
\hline 4. & Biaya Obat-obatan & 518.836 & 437.294 \\
\hline 5. & Biaya TKLK & 4.770 .009 & 2.806 .325 \\
\hline 6. & Biaya Pajak & 55.680 & 55.680 \\
\hline \multicolumn{2}{|l|}{ Jumlah } & 10.610 .376 & 8.267 .683 \\
\hline \multicolumn{2}{|c|}{ Total } & 12.286 .379 & 9.876 .119 \\
\hline \multicolumn{2}{|c|}{ Pendapatan } & 20.037 .859 & 4.748 .912 \\
\hline
\end{tabular}

Sumber: Data diolah, 2020

Tabel 7 menunjukkan bahwa rata-rata pendapatan yang diterima petani pada peremajaan teknik konvensional sebesar Rp. 20.04 juta. Penerimaan petani yang menerapkan teknik konvensional sebesar Rp. 31.89 juta dengan total biaya sebesar Rp. 12.30 juta. Sedangkan rata-rata pendapatan petani yang menerapkan teknik underplanting yaitu sebesar Rp. 4.75 juta. Penerimaan pada petani peremajaan teknik underplanting yaitu sebesar Rp. 14.63 juta dengan total biaya sebesar Rp. 9.88 juta.

\section{Operational cash flow}

Peremajaan Perkebunan sawit teknik konvensional dan teknik underplantng berproduksi selama 8 tahun dan diprediksi selama 25 tahun dengan acuan pedoman buku iyung pahan (2012), yang mana pada teknik konvensional pada tahun 1 dan 2 belum mendapatkan penerimaan karena pada tanaman kelapa sawit belum berproduksi 
lalu pada tahun 3 pada teknik konvensional mulai berproduksi sehingga mendapatkan penerimaan pertama kali sebesar Rp. 6,64 juta sampai tahun ke 25 mendapatkan penerimaan sebesar Rp. 696,64 juta.

Peremajaan teknik underplanting tahun pertama sudah mendapatkan penerimaan karena pada teknik underplanting masih terdapat tanaman tua yang masih berproduksi sehingga mendapatkan penerimaan sebesar Rp. 11,27 juta sampai tahun ke 25 mendapatkan penerimaan sebesar Rp. 315,19 juta. Dapat dilihat tanaman muda pada teknik underplanting pada tahun pertama sampai tahun ke empat rata-rata petani responden belum mendapatkan penerimaan karena tanaman muda pada teknik underplanting belum berproduksi sehingga dapat pertam kali berproduksi pada tahun ke 5 sebesar Rp. 5,16 juta sampai tahun ke 25 mendapatkan penerimaan Rp. 278,16 juta.

\section{Terminal cash flow}

Terminal Cash Flow merupakan tahapan terakhir dalam penyusunan cash flow. Pada tahap ini arus kas mencatat pemasukan dan pengeluaran pada akhir umur ekonomi perkebunan sawit. Meskipun umur ekonomis perkebunan sawit berakhir tetap menghasilkan produksi yang dapat dimasukkan pada arus kas pendapatan, Peremajaan kebun sawit dengan teknik konvensional mendapatkan penerimaan pada tahun ke 25 yakni sebesar Rp. 25,38 juta Peremajaan teknik underplanting mendapat penerimaan sebesar Rp. 10,67 juta. Untuk biaya produksi peremajaan teknik konvensional mengeluarkan modal sebesar Rp. 14,67 juta dan peremajaan teknik underplanting mengeluarkan modal sebesar Rp. 10,16 juta, sementara untuk tanaman muda pada peremajaan teknik underplanting memerlukan modal sebesar Rp. 5,26 juta. Hal tersebut membuat net cash flow atau modal pada tahun terakhir peremajaan teknik konvensional masih bernilai positif pada akhir umur ekonomis sebesar Rp. 13,68 juta, untuk peremajaan teknik underplanting bernilai negatif serta sebesar Rp.-689.

\section{Analisis kriteria kelayakan peremajaan teknik konvensional dan teknik underplanting}

Kelayakan finansial dengan kriteria Net Present Value (NPV), Internal Rate Of Return, Net Bennefit Rasio (Net B/C), dan Payback Period. Adapun discount factor yang digunakan dalam penelitian ini adalah suku bunga yang berlaku yakni sebesar 4,5\%. Adapun hasil analisis finansial dapat dilihat Tabel 8.

Tabel 8. Nilai NPV,Net B/C Ratio, IRR dan payback periode peremajaan teknik konvensiona dan teknik underplanting di Daerah Penelitian Tahun 1 sampai 25 .

\begin{tabular}{clcc}
\hline No & \multicolumn{1}{c}{ Kriteria } & Teknik konvensional & Teknik underplanting \\
\hline 1 & NPV & 271.435 .180 & 83.750 .145 \\
2 & IRR & $61,36 \%$ & $23,15 \%$ \\
3 & Net B/C Ratio & 148,35 & 65,12 \\
4 & Payback Period & 6,25 tahun & 5,80 tahun \\
\hline
\end{tabular}

Sumber: Data diolah, 2020

Berdasarkan Tabel 8 menunjukkan bahwa perkebunan sawit melakukan peremajaan dengen teknik konvensional dan teknik underplanting sama-sama 
memiliki nilai yang positif. Peremajaan teknik konvensional memiliki nilai NPV sebesar Rp. 271,43 juta, nilai IRR sebesar 61,36\%, nilai Net B/C sebesar 148,35 dan nilai payback period selama 6,25 tahun sementara pada peremajaan teknik underplanting menghasilkan nilai NPV sebesar Rp. 83,75 juta, nilai Net B/C sebesar 65,12 dan nilai IRR pada peremajaan teknik underplanting sebesar 23,15\% dan untuk payback periode yaitu 5,80 tahun. Sejalan dengan penelitian Indra et al (2018) bahwa perkebunan sawit di Kecamatan Karang Baru layak diusahakan dimana ditinjau dari NPV > 0, IRR > 12\% dan Net B/CRasio > 1 .

\section{Net present value (NPV)}

Net Present Value (NPV) merupakan nilai perkalian antara arus kas dari tambahan manfaat dan factor diskonto. Perhitungan arus kas dihitung dengan mengurangkan manfaat bruto yaitu nilai produksi dengan total biaya kotor (Ridhwan et al,2018). Perhitungan NPV ini bertujuan untuk mengetahui jumlah total manfaat bersih yang diperoleh suatu usaha dilihat pada nilai saat ini. NPV adalah nilai net benefit yang telah didiskontokan pada tingkat bunga tertentu dengan nilai NPV $>0$ usaha perkebunan kelapa sawit layak untuk diusahakan serta memberikan keuntungan.

Dari Tabel 8 Perhitungan NPV peremajaan konvensional dengan discount factor 12,5\% menghasilkan nilai sebesar Rp. 271,43 juta yang dapat dikategorikan sebagai investasi yang layak secara finansial. Perhitungan NPV pada teknik peremajaan underplanting juga menggunakan discount factor sebesar 12,5\%. Perhitungan NPV menghasilkan nilai sebesar Rp. 83,75 juta. Hal ini dapat dikategorikan sebagai usaha yang layak secara finansial.

Dari Nilai NPV dapat diketahui bahwa peremajaan kebun sawit dengan teknik konvensional dinilai lebih layak digunakan petani karena NPV lebih besar dibandingkan dengan peremajaan teknik underplanting. Selisih nilai NPV peremajaan teknik konvensional dan teknik underpalnting sebesar Rp. 187,68 juta. Peremajaan teknik konvensional lebih layak untuk digunakan petani karena teknik konvensional lebih efisien dan efektif. Penelitian sejalan dengan Susanti,et al (2014), bahwa alternatif model peremajaan konvensional dan underpalnting mampu memberikan keuntungan secara finansial. Peremajaan konvensional dinilai lebih efektif dan efisien dalam pengelolaan dan pengawasan karena terdapat umur tanaman yang relatif sama sehingga akan mengoptimal penggunaan alat-alat produksi dan mengefisienkan biaya operasional.

\section{Net Benefit Cost Ratio (Net B/C)}

Net Benefit Cost Ratio (Net B/C) menunjukkan besarnya benefit yang diperoleh dibandingkan dengan pengorbanan yang telah dikeluarkan (Pasaribu,2012). Analisis ini bertujuan untuk mengetahui berapa besarnya penerimaan dibandingkan dengan pengeluaran selama umur ekonomis kebun sawit.Perolehan nilai $\mathrm{B} / \mathrm{C}>0$ berarti usaha perkebunan kelapa sawit layak untuk diusahakan.

Nilai Net B/C setiap tahunnya akan dihitung selisihnya antara net benefit (+) dan net benefit (-) sehingga diperoleh benefit bersih. Pada peremajaan teknik konvensional nilai benefit bersih sampai pada tahun ke 25 sebesar Rp.442,75 juta, kemudian nilai net benefit (+) sebesar Rp.451,57 juta ini dijadikan pembilang. Nilai Net benefit 
perkebunan sawit peremajaan teknik konvensional sebesar 148,35. Hal ini berarti setiap tambahan biaya sebesar Rp. 1,00 akan memperoleh tambahan manfaat bersih sebesar Rp.148,35. Nilai Net benefit perkebunan sawit peremajaan underplanting sebesar 65,12. Hal ini berati setiap tambahan biaya sebesar Rp. 1,00 akan memperoleh tambahan manfaat bersih sebesar Rp. 65,12. Hasil penelitian ini jauh lebih rendah dibandingkan nilai net benefit (Ridhwan et al, 2018) di daerah Kabupaten Ketapang.

\section{Internal rate of return (IRR)}

Perhitungan IRR adalah dengan cara coba-coba selama NPV masih positif, discount factor terus ditambah sampai pada nilai positif dan negatif untuk nilai berikutnya. IRR terletak diantara kedua NPV tersebut.Peremajaan teknik konvensional percobaan menggunakan discount factor sebesar $25 \%$ dan $27 \%$ maka nilai NPV yang diperoleh yakni Rp. 0,353 juta, dan -Rp. 0,241 juta, sehingga sudah memenuhi syarat nilai IRR yaitu mendapatkan nilai NPV positif dan NPV negatif diantara 2 discount factor yang digunakan selisih tingkat discount factor adalah 2\%. Setelah dilakukan perhitungan pada NPV positif dan NPV negatif maka diperoleh nilai IRR sebesar $51,45 \%$ yang artinya tingkat pengembalian usaha terhadap setiap satuan modal adalah $51,45 \%$. Nilai IRR peremajaan teknik underplanting hanya sebesar 32,43\%. Jika dibandingkan besarnya bunga bank umum yang berlaku $12 \%$ maka disimpulkan kedua pola peremajaan layak secara finansial.

\section{Payback period (PP)}

Payback Period bertujuan untuk melihat jangka waktu yang diperlukan untuk mengembalikan biaya investasi,yang nilainya akan dibandingkan dengan umur usaha kebun sawit (Ridhwan et al, 2018). Besarnya nilai investasi peremajaan teknik konvensional dan teknik underplanting sebesar Rp. 22,43 juta dan Rp.20,05 juta. Besarnya nilai investasi digunakan sebagai pembilang, menurut Jakfar (2012) karena kas bersih setiap tahun berbeda maka penyelesaiannya adalah dengan mengurangkan net benefit. Payback period pada peremajaan teknik konvensional selama 6,25. Sementara itu hasil perhitungan payback period pada peremajaan teknik underplanting adalah selama 5,80. Hal ini berarti jangka pengembalian investasi pada kebun sawit peremajan teknik underplanting lebih cepat dibandingkan dengan peremajaan teknik konvensional.

\section{Analisis sensitivitas}

Analisis sensitivitas ditujukan untuk menilai kembali dan melihat pengaruh komponen manfaat dan biaya terhadap kelayakan usaha yang akan terjadi akibat keadaan yang berubah-ubah. Analisis sensitivitas yang telah dilakukan dengan mencari rata-rata kenaikan nilai tukar setiap tahunnya yang terjadi pada tahun 2012-2035. Hasil analisis sensitivitas yang telah dilakukan terjadi perubahan pada NPV,IRR,Net B/C, dan Payback Period jika terjadi perubahan pada kenaikan biaya variabel dan penurunan harga TBS. Pada analisis sensitivitas ini ada 2 skenario yang digunakan: (1) Harga faktor produksi diasumsikan naik sebesar 15\%, sedangkan harga jual TBS diasumsikan 
naik 15\%, (2) Harga jual TBS turun sebesar 15\% dan harga faktor produksi dianggap tetap. Hasil analisis ini dapat dilihat Tabel 9.

Tabel 9. Hasil analisis sensitivitas kebun kelapa sawit rakyat di Kabupaten Muaro Jambi

\begin{tabular}{|c|c|c|c|c|c|}
\hline \multirow[b]{2}{*}{ No } & \multirow[b]{2}{*}{$\begin{array}{l}\text { Kriteria } \\
\text { Kelayakan }\end{array}$} & \multicolumn{2}{|c|}{ Peremajaan Konvensional } & \multicolumn{2}{|c|}{ Peremajaan Underplanting } \\
\hline & & $\begin{array}{c}\text { Harga } \\
\text { Faktor } \\
\text { Produksi } \\
\text { Naik 15\% } \\
\text { dan Harga } \\
\text { TBS Tetap }\end{array}$ & $\begin{array}{c}\text { Harga Jual } \\
\text { TBS Turun } \\
\text { 15\% dan } \\
\text { Harga } \\
\text { Faktor } \\
\text { Produksi } \\
\text { Tetap } \\
\end{array}$ & $\begin{array}{c}\text { Harga } \\
\text { Faktor } \\
\text { Produksi } \\
\text { Naik 15\% } \\
\text { dan Harga } \\
\text { TBS Tetap }\end{array}$ & $\begin{array}{c}\text { Harga Jual } \\
\text { TBS Turun } \\
\text { 15\% dan } \\
\text { Harga } \\
\text { Faktor } \\
\text { Produksi } \\
\text { Tetap }\end{array}$ \\
\hline 1 & $\begin{array}{l}\text { Net Present } \\
\text { Value }\end{array}$ & 489.752 .450 & 175.160 .135 & 75.132 .435 & 60.125 .432 \\
\hline 2 & $\begin{array}{l}\text { Internal Rate of } \\
\text { Return }\end{array}$ & 45,75 & 22,41 & 19,75 & 16,25 \\
\hline 3 & $\begin{array}{l}\text { Benefit Cost } \\
\text { Ratio }\end{array}$ & 82,95 & 23,34 & 35,62 & 19,52 \\
\hline 4 & Payback Period & 5,85 & 7,22 & 6,32 & 8,35 \\
\hline
\end{tabular}

Kenaikan harga faktor produksi 15\% yang diikuti dengan kenaikan harga TBS 15\% menyebabkan nilai NPV kenaikan dari Rp. 271,43 juta menjadi sebesar Rp. 489,75 juta. Sedangkan apanila TBS turu n 15\% dan harga faktor produksi naik $15 \%$ maka terjadi penurunan NPV dari Rp.271,43 juta turun menjadi Rp. 175,16 juta. Penelitian Andi,B ( 2019 ) di daerah Kecamatan Baras Kabupaten Pasangkayu bahwa sebesar 7\% menyebabkan kenaikan nilai NPV dari Rp.550,79 juta menjadi Rp.1,92 miliar dan penelitian Purwonugroho et al (2013) di Desa Galuh Kecamatan Tapung Kabupaten Kampar bahwa sebesar 13,54\% menyebabkan kenaikan dari nilai NPV Rp. 459,48 juta,- menjadi Rp. 52,71 juta. BCR turun dari 2,61 menjadi 2,56. Penelitian Kariyasa ( 2015) di daerah Provinsi Kalimantan Barat bahwa BCR naik 1,27 menjadi 1,72 dan penelitian Susanti et al (2014) di Desa Sungai Lambu Makmur Kecamatan Tapung Kabupaten Kampar bahwa nilai BCR naik dari 6,74 menjadi 10,81. PBP menjadi lebih panjang dari 5,24 tahun menjadi 5,92 tahun. Penelitian Eko et altahun 2017di daerah Kecamatan Rasau Jaya Kabupaten Kubu Raya bahwa nilai PBP sama yaitu 6,8 tahun.

Penurunan nilai NPV lebih besar pada peremajaan underplanting yaitu turun dari Rp. 83,75 juta,- menjadi Rp. 75,13 juta,- atau turun sebesar 15\%. Nilai IRR turun dari 23,12 menjadi 19,75. Penelitian Andi,B tahun 2019 di daerah Kecamatan Baras Kabupaten Pasangkayu bahwa nilai IRR meningkat dari 30 menjadi 37. BCR turun dari 2,18 menjadi 2,14 dan penelitian Ocenia et al (2018) di Desa Sari Makmur Kecamatan Pangkalan Lesung Kabupaten Pelalawan bahwa nilai IRR meningkat dari 34,10 menjadi 34,42. PBP menjadi lebih panjang dari 5,05 tahun menjadi 5,85 tahun. Sama halnya untuk BEP, waktu pengembalian total costnya lebih lama dari 9,23 tahun menjadi 10,65 tahun. Hal yang sama juga terjadi pada saat harga tandan buah segar 
(TBS) diturunkan sebesar $10 \%$. Sebelum pembiayaan terjadinya penurunan nilai NPV dari Rp. 126,47 juta,- menjadi Rp.114,42 juta,- atau turun sebesar 9,52\% dari nilai NPV sebelumnya. Nilai IRR turun dari 28,37 menjadi 28,00. BCR turun dari 2,61 menjadi 2,54. PBP menjadi lebih panjang dari 5,24 tahun menjadi 5,95 tahun.

\section{KESIMPULAN DAN SARAN}

\section{Kesimpulan}

Model peremajaan perkebunan sawit rakyat baik model konvensional maupun underplanting layak untuk digunakan petani. Kriteria investasi kedua model peremajaan perkebunan sawit menghasilkan nilai NPV, Net B/C, IRR dan Payback Period cukup menguntungkan petani. Model peremajaan perkebunan sawit lebih baik menggunakan model konvensional karena dapat menghasilkan produktivitas yang lebih tinggi dan pengelolaan kebun lebih efisien dibandingkan model peremajaan underplanting.

Respon perubahan nilai NPV, Net b/c, IRR dan payback period responsive terhadap perubahan harga TBS dibandingkan kenaikan harga faktor produksi. Kenaikan nilai-nilai NPV, Net b/c, IRR dan payback period sangat besar apabila terjadi kenaikan TBS. baik pada model peremajaan konvensional dan model underplanting. Model konvensional lebih responsive dari model underplanting apabila terjadi kenaikan harga TBS.

\section{Saran}

Produktivitas perkebunan sawit rakyat baik model peremajaan konvensional maupun model underplanting tergolong sangat rendah, sehingga diperlukan adopsi teknologi dengan penggunaan input produksi sesuai anjuran yang memungkinkan terjadinya peningkatan produktivitas. Kelayakan finansial akan menjadi lebih baik lagi jika terjadi peningkatan produktivitas kebun sawit, dan dapat menjamin terjadinya provitbilitas jangka panjang.

\section{DAFTAR PUSTAKA}

Alfizar S, Hasyim I.A, \& Affandi I.M. (2017). Analisis kelayakan finansial kelapa sawit di Kabupaten Lampung Tengah. Journal of Agribusiness Science, 5(3), 228-234

Arianto, E. (2008). Pertumbuhan produksi minyak sawit Indonesia 1964-2007, diakses dalamhttps://strategika.wordpress.com/2008/12/05/pertumbuhan-sawitindonesia/, Tanggal 1 Januari 2020, Pukul 12.30 WIB

Badan Pusat Statistik. (2014). Luas dan produksi perkebunan menurut jenis tanaman, Indonesia 2010-2013. Badan Pusat Statistik: Jakarta

Badan Pusat Statistik. (2015). Statistik kelapa sawit Indonesia 2015-2018, diakses dalam http://bps.go.id, Tanggal 2 Januari 2020, Pukul 12.30 WIB

Balqis A. (2020). Analisis kelayakan finansial usahatani kelapa sawit di Kecamatan Baras Kabupaten Basangkayu. Fakultas Ekonomi. Universitas Negeri Makassar.Sulawesi Selatan. 
Badan Pusat Statistik. (2015). Statistik kelapa sawit Indonesia 2015-2017. Badan Pusat Statistik.

Delfidelwina. (2013). Penilaian kelayakan finansial kebun kelapa sawit rakyat di Kabupaten Rokan Hulu. Jurnal Agroekonomi, 24 (1): 99 - 110.

Dwijatenaya IBMA, Nugroho AE, Hakimin. (2019). kelayakan finansial usahatani kelapa sawit (suatu studi kasus). Jurnal "Gerbang Etam” Balitbangda 13(1): 45-52.

Fauzi, Y. (2012). Kelapa sawit. edisi revisi. Swadaya: Jakarta.

Ginting E.N, Edy Sigit,Sutarta,Suroso R, Heri S,Agus S. (2008). Peremajaan tanaman kelapa sawit sistem underplanting keunggulan dan kelemahannya.Pusat Penelitian Kelapa Sawit.Medan

Herman, Agus F, Las Irsal. (2009). Analisis finansial dan keuntungan yang hilang dari pengurangan emisi karbondioksida pada perkebunan kelapa sawit. Jurnal Litbang Pertanian 28 (4). B

Ibrahim, Y. (2009). Studi kelayakan bisnis. Rinekka Cipta: Jakarta.

Indra, SB, Rozalina, Nudin. O.F.(2018). Analisis kelayakan finansial usaha pembibitan kelapa sawit pada UD. Jaya Tani Kecamatan Karang Baru Kabupaten Aceh Tamiang. Jurnal Agrisamudra 5(1): 49 - 58.

Juliansyah Hijri,Moulida Putri,Apridar. (2020). Analisis Faktor-Faktor Yang Mempengaruhi Cadangan Devisa Indonesia. Jurnal Ekonomi Regional Unimal.3 (2)

Kariyasa K.I. (2015). Analisis Kelayakan Finansial Penggunaan Bibit Bersertifikat Kelapa Sawit di Provinsi Kalimantan Barat. Jurnal Agro Ekonomi, 33(2), 141159.

Ocenia Yolanda., Yusmini., dan Etwina Susi. (2018). Analisis kelayakan finansial sistem integrasi dan kelapa sawit dengan sistem pemeliharan semi intensif (studi kasus pada kelompok tani sarwo sari di Desa Sari Makmur Kecamatan Pangkalan Lesung Kabupaten Pelalawan). Journal Agribusiness and Community Empowerment. 2(2), 49-57.

Pahan, I. (2008). Panduan lengkap kelapa sawit dari Hulu Ke Hilir. Swadaya: Jakarta

Pasaribu, A. M. (2012). Perencanaan dan Evaluasi Proyek Agribisnis. Yogyakarta: Lily Publisher.

Purwonugroho Taufik., Yusmini dan Tarumun Suardi. (2013). Analisis kelayakan peremajaan usaha perkebunan kelapa sawit pola plasma di Desa Sari Galuh Kecamatan Tapung Kabupaten Kampar. Fakultas Pertanian Universitas Riau (Jurnal). Riau.

Ramadhannissa, Rachmalia. (2013). Analisis kelayakan usaha perkebunan Kelapa Sawit Pt. Terang Inti Seraya di Provinsi Riau. Fakultas Ekonomi dan Manajemen IPB: Bogor.

Ridhwan, Muani Ani, Komariyati. (2018). Analisis kelayakan investasi perusahaan perkebunan PT. Ladang Sawit Kendawangan di Kabupaten Ketapang. Jurnal Social Economic of Agriculture, 7 (2): 120-139.

Susanti Eti., Utabarat Sakti dan Muwardi Didi. (2014). Analisis perbandingan alternatif model peremajaan Kelapa Sawit konvensional dengan underplanting pola perkebunan inti rakyat (PIR) di Desa Sungai Lambu Makmur Kecamatan 
Tapung Kabupaten Kampar. Fakultas Pertanian Universitas Riau. Jom Faperta, $1(2)$.

Tarigan IS, Hutabarat S, Tarumun S. (2014). Analisis kinerja finansial usaha perkebunan Kelapa Sawit Rakyat di Kabupaten Pelalawan.Fakultas Pertanian. Universitas Riau.Riau.

Utomo. EB, Yurisinthae. E, Hidayat. R. (2017). Analisis kelayakan finansial usaha perkebunan kelapa sawit rakyat. Fakultas Pertanian.Universitas Tanjungpura. Pontianak. 